\title{
What Brings International Students to Norway?
}

\author{
Jannecke Wiers-Jenssen \\ Oslo Metropolitan University, Norway
}

Norway has experienced a substantial influx of students in the 21 st century. The number of students with foreign citizenship has increased from just over 5,000 in 2000 to more than 23,000 in 2018, as seen in Figure 1 (DBH, 2020). This growth may seem like a paradox, given that Norway has few well-known higher education institutions, high living expenses, a language not widely understood, and a geographical location at the northern fringes of Europe.

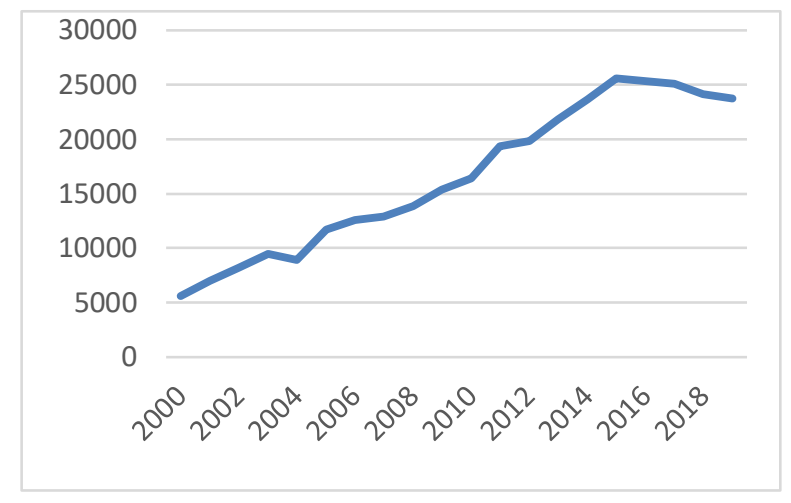

Figure 1: Number of Bachelor and Master Students in Norway with Foreign Citizenship 2000-2018

So why do students choose Norway? A deliberate policy for internationalization of higher education developed is an important factor. From the 1980s, internationalization has increasingly become an integral part of national higher education policies as well as included as strategies of higher education institutions (Wiers-Jenssen \& Sandersen, 2017). The main rationale for encouraging student 
mobility is educational; mobility is seen a tool for quality enhancement in higher education. However, economic, cultural, and political rationales are also present. The fact that the vast majority of higher education institutions are public partly explains why internationalization policies quite efficiently has trickled down from the national to the institutional level.

Most Norwegian higher education institutions do not charge tuition fees. This has gradually become a comparative advantage, as an increasing number of neighboring countries have introduced fees for students from outside Europe. Hence, there may be economic rationales for choosing Norway as a study destination, despite high costs of living. Students from developing countries may qualify for funding from the Norwegian government, while students from other countries have to cover all expenses themselves.

Higher education institutions have economic incentives other than tuition fees for attracting international students. A reform in Norwegian higher education implemented in 2003 introduced a performance-based funding system (Frölich, 2006). Higher education institutions are rewarded for the number of credit points awarded, implying a stronger focus on attracting students in general. A significant increase in the number of courses and programs in English has facilitated recruitment of international students (Wiers-Jenssen, 2019).

International students cited courses in English and absence of tuition fees as the most frequently reported motives for studying in Norway (Diku, 2019a; WiersJenssen, 2019). The latter is particularly important for students undertaking a full degree in Norway. Features of Norway, such as peaceful, safe, and technologically advanced society and unspoiled countryside are also accentuated. As these characteristics were present also before the number of international students started to grow, such motives must be understood in relation to conditions that have changed, such as availability of courses in English. Beautiful scenery and safety would have limited attractional value if courses in English were not offered.

Quality is a less highlighted reason for choosing Norway as a study destination. But even if perceived quality is not a main attraction, international students in general give positive assessments of the quality of their education (Diku, 2019a). They cope quite well with academic demands, and their main challenges seem to be dealing with the high living expenses and limited interaction with Norwegians. The latter represents a challenge also for higher education institutions, as a major rationale for recruiting international students is to enhance "internationalization at home" (exposing Norwegian students and faculty to perspectives from abroad). If interaction is scarce, so is the exchange of ideas and perspectives.

Foreign students in Norway consist of three groups (see Figure 2): (a) students who come to undertake a full postgraduate degree (international graduate students), corresponding to the definition of international students used in the Organisation for Economic Cooperation and Development (OECD, 2020) statistics; (b) students who come for a shorter study of 3 months or more (international exchange students); and (c) students who come for study sojourn of less than three months or who have come to Norway for other reasons, including (labor) migrants, refugees and more. In total, these three groups constituted $8.7 \%$ of total enrollments in Norwegian higher education institutions in 2018 (own calculation based on DBH). 


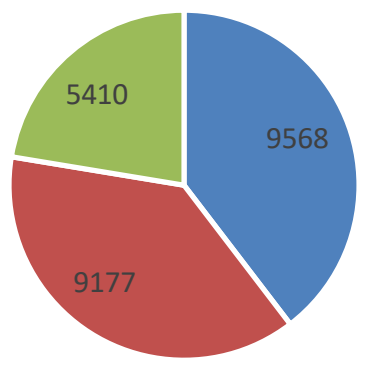

- International graduate students

- International exchange students

Other students with foreign citizenship

\section{Figure 2: Bachelor and Master students in Norway with Foreign Citizenship, 2018: Number and Type of Students}

$\mathrm{PhD}$ students are not included in the figures mentioned above, and an exact number of current doctoral students cannot be estimated. However, the number of foreign citizens completing a $\mathrm{PhD}$ was 657 in 2018, 42 per cent of all $\mathrm{PhD}$ graduates (Research Council of Norway, 2019). Hence, the proportion of foreign citizens is far higher at the doctorate level than at the bachelor and master level. This is in line with the situation in most European and North American countries (OECD, 2019).

The largest universities (University of Oslo and Norwegian University of Science and Technology) attract the highest number of international students. These are also among the few Norwegian higher education institution found on international ranking lists. However, some small specialized higher education institutions such as the Academy of Fine Art, The Oslo School of Architecture and Design, and the Norwegian Academy of Music have higher proportions of international students.

The majority of international students originate from Europe and Asia (Diku, 2019b). China, Nepal, Sweden and Germany are currently the major sending countries of full degree students. Exchange students are mainly Europeans, and many of these come through the European Union student exchange program ERASMUS. European exchange students are often attracted by the "exoticness" of studying in the northern fringes of Europe. The majority of full degree students are enrolled in master programs, while exchange students are in bachelor programs. Science and technology is the most popular field of study, and clearly more popular among international students than Norwegian students (Diku, 2019b).

More than half of the international students report being interested in living and working in Norway upon graduation (Diku, 2019a). However, updated statistics on the number that actually settle in Norway are currently not available. While obtaining a residence permit in Norway is quite straightforward for those who are originate from countries in the European Economic Area, students from other countries generally face more barriers. Some countries see recruitment of international students as an instrument for so-called skilled migration, but Norway does not have an explicit policy on this. On the contrary, government policies have encouraged students to 
leave upon graduation, in order to avoid poaching highly skilled individuals from countries that already experience high emigration. As a part of foreign aid policy, students from developing countries have received grants for studying in Norway, on condition that they return to their home country.

The last couple of years, the number of international students in Norway has ceased to grow (cf. Figure 1). The reasons for this are not clear. It may be that a (temporary) point of saturation is reached. Still, the overall picture shows a remarkable growth in the last two decades. This illustrates that a small country with weak traditions for inward mobility may be able to attract international students if higher education institutions and national policies match well. Further, it shows that institutional policies can attract international students as much as economic policies.

\section{REFERENCES}

Diku. (2019a). Tilstandsrapport for høyere utdanning 2019 (Annex report). Bergen: Norwegian Agency for International Cooperation and Quality Enhancement in Higher Education.

Diku. (2019b). International students in Norway. Contributors to quality in higher education. https://diku.no/en/reports/international-students-in-norwaycontributors-to-quality-in-higher-education

Organisation for Economic Cooperation and Development. (2020). International student mobility (indicator). doi:10.1787/4bcf6fc3-en

Research Council of Norway. (2019). Science and technology indicators for Norway, 2019. Lysaker: The Research Council of Norway

Strehl, F., Reisginer, S., \& Kalatschan, M. (2007). Funding systems and their effects on higher education systems. OECD Education Working Papers, No. 6. https://doi.org/10.1787/220244801417

Wiers-Jenssen, J. (2019). Paradoxical attraction? Why an increasing number of international students choose Norway. Journal of Studies in International Education, 23(2), 281-298.

Wiers-Jenssen, J. and Sandersen, H. (2017). The Norwegian Framework for Educational Cooperation with Russia: Educational policy with a hint of foreign affairs. In Sundet, M. Forstorp P.A. and Örtenblad, A. Higher Education in the High North. Dordrecht: Springer.

JANNECKE WIERS-JENSSEN, PhD, is an associate professor at the Centre for the Study of Professions, Oslo Metropolitan University, Norway. She holds an adjacent position at the Nordic Institute for Studies in Research and Education (NIFU). Her main research interest is international student mobility, but her publications also cover the transition from higher education to work, student assessments of quality, medical education and more. Email: jann@oslomet.no 